\title{
Serotonergic Neurons Are Targets for Leptin in the Monkey*
}

\author{
PATRICIA D. FINN††, MATTHEW J. CUNNINGHAM $\$$, DIANA G. RICKARD, \\ DONALD K. CLIFTON, AND ROBERT A. STEINER
}

Departments of Physiology and Biophysics (P.D.F., D.G.R., R.A.S.) and Obstetrics and Gynecology (D.K.C., R.A.S.), Graduate Program in Neurobiology and Behavior (M.J.C.), and the Specialized Cooperative Centers Program in Reproduction Research (D.K.C., R.A.S.), University of Washington, Seattle, Washington 98195

\begin{abstract}
Leptin is a secretory product of adipocytes that has been shown to affect food intake, metabolism, and reproduction. One site of leptin's action is the central nervous system, where the leptin receptor $(\mathrm{Ob}-\mathrm{R})$ messenger ribonucleic acid (mRNA) and protein are expressed in discrete areas. In both the rat and monkey, Ob-R mRNA has been localized in the Raphe nuclei of the brainstem. Neurons in the Raphe nuclei are the primary source of serotonin in the brain. Serotonergic pathways influence both feeding and reproduction, and these cells are plausible direct targets for leptin's action. We used double label in situ hybridization and computerized image analysis to determine whether serotonergic neurons in the brainstem of the female pigtailed ma-
\end{abstract}

caque (Macaca nemestrina) express Ob-R mRNA. We observed that many cells in the Raphe nuclei express serotonin transporter mRNA, a marker of serotonergic cells, and Ob-R mRNA. Based on quantitative analysis, the highest number of cells that express both serotonin transporter and Ob-R mRNAs were found in the caudal dorsal Raphe and median Raphe nuclei; fewer double labeled cells were situated in the caudal linear nucleus and rostral median Raphe, whereas double labeled cells occurred infrequently in the rostral dorsal Raphe. These observations suggest that leptin may act on serotonergic cells to mediate some of its effects on ingestive behavior, metabolism, and reproduction. (J Clin Endocrinol Metab 86: 422-426, 2001)
L EPTIN IS A protein product of the obese $(o b)$ gene and is secreted primarily by adipocytes. Leptin regulates body weight and metabolism and may also act as a metabolic signal to the reproductive axis $(1,2)$. Animals that have mutations in the genes that code for either leptin (e.g. ob/ob mice) or its receptor (Ob-R; e.g. $d b / d b$ mice and fa/fa rats) are hyperphagic, obese, and infertile $(3,4)$. These abnormalities are corrected in $o b / o b$ mice by treatment with exogenous leptin $(5,6)$. In rodents as well as nonhuman primates, central injections of leptin result in decreased food intake $(6,7)$, suggesting that leptin acts directly on the brain to regulate this physiological process. Fasting results in a decline in circulating leptin levels (8) as well as a reduction in the activity of the neuroendocrine reproductive axis, as evidenced by a decrease in plasma levels of $\operatorname{LH}(9,10)$. Both central and peripheral administration of leptin to fasted animals prevents the suppression of LH secretion (11-13).

Although it would appear that leptin acts on the brain to

Received June 2, 2000. Revision received September 25, 2000. Accepted October 3, 2000

Address all correspondence and requests for reprints to: Dr. Robert A. Steiner, Department of Physiology and Biophysics, Box 357290, University of Washington, Seattle, Washington 98195-7290. E-mail: steiner@u.washington.edu.

* This work was supported by the NICHHD/NIH through Cooperative Agreement 3U54-HD-12629-20S1 as part of the Specialized Cooperative Centers Program in Reproduction Research. Support for this research was also provided by the NIH (Grants F32-HD08129, T32HD07453, P50-HD-12629, and RR00166) and the Andrew W. Mellon Foundation.

† Present address: Ligand Pharmaceuticals, Inc., 10275 Science Center Drive, San Diego, California 92121.

$\ddagger$ These authors contributed equally to this work. affect feeding and reproduction, the neural circuitry mediating leptin's action in the central nervous system has yet to be fully elucidated. To date, the majority of effort in mapping this circuitry has focused on the hypothalamus, an area of the brain known to be involved in the regulation of ingestive behaviors, metabolism, and reproduction (14). This is due to the abundant expression of Ob-R messenger ribonucleic acid (mRNA) in several hypothalamic nuclei $(12,15)$. Recently, we identified cells in the dorsal Raphe nucleus (DR) in pigtailed macaques (Macaca nemestrina) that express Ob-R mRNA (12), corroborating a similar observation in the rat reported by Elmquist et al. (15). Neurons located in the Raphe nuclei are the primary source of serotonin (5-HT) in the brain. Based on this observation and evidence that 5-HT has pronounced effects on both feeding and reproduction $(16,17)$, we postulated that 5-HT neurons in the brain stem are direct targets for leptin's action. To test this hypothesis, we used double label in situ hybridization (ISH) to determine whether cells that express Ob-R mRNA also express the mRNA for the serotonin transporter (SERT), a highly specific marker for 5-HT neurons (18). Using computer imaging and quantitative analysis, we mapped the distribution of $\mathrm{Ob}-\mathrm{R}$ mRNA in relation to SERT mRNA and report the numbers of cells that express both mRNAs in various divisions of the Raphe nuclei in the pigtailed macaque brain.

\section{Materials and Methods \\ Experimental animals}

Tissue was obtained from adult female pigtailed macaques (Macaca nemestrina; 6.4 and $9.5 \mathrm{yr}$ of age; $\mathrm{n}=2$ ) through the Tissue Distribution Program at the Regional Primate Research Center at the University of Washington. All procedures were approved by the animal care com- 
mittee of the School of Medicine at the University of Washington, in accordance with the NIH Guide for the Care and Use of Laboratory Animals.

\section{Tissue preparation}

Animals were first sedated with ketamine and then overdosed with sodium pentobarbital. Approximately $20 \mathrm{~min}$ later, the brain was removed and dissected. A block of tissue containing the midbrain and pons was obtained by laying the brain ventral side up and making a coronal cut caudal to the mammillary bodies. Occipital cortex and portions of the cerebellum were removed, and the block was cut caudally at the pontine-medullary junction. Tissues were frozen immediately on dry ice and stored at $-80 \mathrm{C}$. Cryostat sections were cut at $20 \mu \mathrm{m}$, thaw-mounted onto SuperFrost Plus slides (Fisher Scientific, Pittsburgh, $\mathrm{PA})$, and stored at $-80 \mathrm{C}$.

\section{Riboprobe preparation}

${ }^{33} P$-Labeled Ob-R complementary RNA (cRNA) riboprobe. A construct was provided by Joseph Kuijper (ZymoGenetics, Inc., Seattle, WA), which contains a 380-bp fragment of complementary DNA (cDNA) coding for the human Ob-R inserted within Bluescript S/K (Stratagene, La Jolla, CA). This fragment is complementary to bases 1016-1396 (amino acids 275-402) in the extracellular domain of the receptor. The cDNA was linearized with EcoRI (New England Biolabs, Inc., Beverly, MA), and the radiolabeled antisense $\mathrm{RNA}$ probe was synthesized in vitro by inclusion of the following ingredients in a volume of $20 \mu \mathrm{L}$ : $250 \mathrm{pmol}\left[{ }^{33} \mathrm{P}\right] \mathrm{UTP}$ (NEN Life Science Products, Boston, MA); linearized cDNA (2 $\mu \mathrm{g})$; T7 RNA polymerase (Roche Molecular Biochemicals, Indianapolis, IN); $1 \times$ transcription buffer; $500 \mu \mathrm{mol} / \mathrm{L}$ ATP, CTP, and GTP; and ribonuclease (RNase) inhibitor (Stratagene, La Jolla, CA). Residual DNA template was digested by incubation with deoxyribonuclease (Stratagene), and this reaction was terminated by addition of $2 \mu \mathrm{L} 0.5 \mathrm{~mol} / \mathrm{L}$ ethylenediamine tetraacetic acid (pH 8.0). Finally, $1 \mu \mathrm{L}$ yeast transfer RNA $(10 \mathrm{mg} / \mathrm{mL})$ was added as a carrier. The cRNA was separated from unincorporated nucleotides on a Quick Spin Sephadex G-50 column (Roche).

Digoxigenin-labeled SERT cRNA riboprobe. A 253-bp cDNA fragment of the human SERT gene, which was generated by PCR using the fulllength human SERT cDNA as a template $(19,20)$, was provided by Dr. Cynthia Bethea (Oregon Regional Primate Research Center, Beaverton, OR). The cDNA was linearized with NotI (New England Biolabs, Inc.), and the cRNA probe was transcribed in vitro in a volume of $40 \mu \mathrm{L}$ containing linearized cDNA $(4 \mu \mathrm{g}), 1 \times$ DIG RNA labeling mix containing digoxigenin-11-UTP (Roche), SP6 RNA polymerase (Roche), $1 \times$ transcription buffer, and RNase inhibitor. Residual DNA template was digested by incubation with deoxyribonuclease, and this reaction was terminated by addition of $2 \mu \mathrm{L} 0.5 \mathrm{~mol} / \mathrm{L}$ ethylenediamine tetraacetic acid ( $\mathrm{pH}$ 8.0). The cRNA was separated from unincorporated nucleotides on a Quick Spin Sephadex G-50 column. The optimal concentration of the SERT riboprobe was determined empirically.

\section{Double label ISH}

To identify cells that contain both Ob-R and SERT mRNA, we performed double label ISH using slight modifications of previously published protocols $(12,21)$. Briefly, the tissue was fixed with $4 \%$ paraformaldehyde, acetylated, and delipidated. Next, prehybridization solution, consisting of $25 \%$ transfer RNA $(10 \mathrm{mg} / \mathrm{mL})$ in hybridization buffer, was applied to the sections, which were then covered with silane-coated glass coverslips and incubated in humid chambers for $2 \mathrm{~h}$ at $55 \mathrm{C}$. The sections were rinsed in $2 \times$ SSC (standard saline citrate), dehydrated with ethanol, and air-dried. Next, hybridization buffer containing freshly denatured ${ }^{33} \mathrm{P}$-labeled Ob-R cRNA probe $\left(6.8 \times 10^{5}\right.$ $\mathrm{cpm} / \mu \mathrm{L}$ ), digoxigenin-labeled SERT cRNA probe, and transfer RNA $(1.7 \mathrm{mg} / \mathrm{mL})$ was applied to the tissue. Slides were covered with silanecoated glass coverslips and incubated in humid chambers overnight at $57 \mathrm{C}$. The following day, the tissue was treated with RNase A and washed under conditions of increasing stringency, including two successive 30 -min washes at $60 \mathrm{C}$ in $0.1 \times$ SSC. The tissue was then blocked for $60 \mathrm{~min}$ with $2 \%$ normal sheep serum, incubated with antidigoxigenin fragments conjugated to alkaline phosphatase (Roche) diluted 1:1000 for
$3 \mathrm{~h}$ at $37 \mathrm{C}$, and kept at $4 \mathrm{C}$ overnight. The next day, slides were incubated in a chromagen reaction with 4-nitro blue tetrazolium-chloride 340 $\mu \mathrm{g} / \mathrm{mL}$; Roche), 5-bromo-4-chloro-3-indolyl phosphate $(175 \mu \mathrm{g} / \mathrm{mL}$; Roche), and levamisole ( $240 \mu \mathrm{g} / \mathrm{mL})$ until cells were clearly visible at the light microscopic level. The slides were then dipped briefly in $70 \%$ ethanol, air-dried, and coated in 3\% parlodion dissolved in isoamyl acetate. After air-drying, the slides were dipped in NTB-3 emulsion (Eastman Kodak Co., Rochester, NY), exposed for 11 days, and developed.

\section{Control experiments}

The identity and integrity of the ${ }^{33} \mathrm{P}$-labeled $\mathrm{Ob}-\mathrm{R}$ cRNA probe were verified by PAGE against known standards. The integrity of the digoxigenin-labeled SERT cRNA probe was verified by agarose gel electrophoresis. The results of sense controls with these probes have been documented previously $(12,19)$.

\section{Analysis}

Coexpression of SERT and Ob-R mRNAs within the same cells was analyzed in a manner similar to a previously published protocol (12) The brainstem Raphe nuclei were divided into several regions along the rostral to caudal axis using the Template Atlas of the Primate Brain as a guide (http://rprcsgi.rprc.washington.edu/ atlas), and representative sections were chosen from each animal for each region. The most rostral section contained the caudal linear Raphe nucleus (CLi; Fig. 1A). More caudally, the Raphe nuclei were divided into the DR and median Raphe (MR) by the medial longitudinal fasciculus. The DR and MR were further subdivided into rostral (Fig. 1B) and caudal (Fig. 1C) portions by the appearance medially of the cerebellum and the fourth ventricle. Thus, a representative section from each of five areas (CLi, rostral DR, rostral MR, caudal DR, and caudal MR) was chosen per animal for analysis. Atlas plates were chosen to represent these regions, and the distribution of Ob-R mRNA- and SERT mRNA-containing cells was transferred to these plates (Fig. 1).

Sections were viewed under a microscope, and images were captured with a Cohu 4910 camera (San Diego, CA) attached to a Macintosh IIfx (Apple Computer, Cupertino, CA). Using custom-designed software, we identified SERT mRNA-containing neurons and then counted the number of silver grains (corresponding to Ob-R mRNA) over each cell. Every positively identified SERT mRNA-expressing cell was counted on one half of each section. An average of $76 \pm 20$ cells were counted per anatomical region per animal $(\sim 0.5 \%$ of the total number of SERT mRNA-expressing cells). Signal to background ratios (SBRs) for individual cells were calculated as previously described (22). For each animal, the number of counted cells with a SBR greater than a particular value $($ e.g. $0,1,2$, etc. $)$ was calculated and then converted to a percentage of the total counted cells (cumulative frequency curve). The percentages at each SBR interval were averaged across animals to produce means and SEMS. The percentage of cells deemed to be double labeled was compared among anatomical regions at a SBR criterion of 5 by one-way ANOVA with repeated measures.

\section{Results}

We determined the distribution of $\mathrm{Ob}-\mathrm{R}$ mRNA in the rostral brainstem of the macaque. As reported previously (12), Ob-R mRNA was found in the DR. Further examination revealed the presence of $\mathrm{Ob}-\mathrm{R}$ mRNA in the CLi and MR as well. Ob-R mRNA was also found outside the Raphe nuclei in the midbrain tegmentum immediately dorsal to the substantia nigra.

The majority of SERT mRNA-containing cells were found in the CLi, DR, and MR. The locations of these cells at different levels of the macaque brain stem are illustrated in Fig. 1. SERT mRNA-containing neurons with overlying clusters of silver grains, indicating the presence of Ob-R mRNA (Fig. 2 ), were found in all three Raphe nuclei. Measurements of SBRs for Ob-R mRNA in SERT mRNA-positive cells are 
A
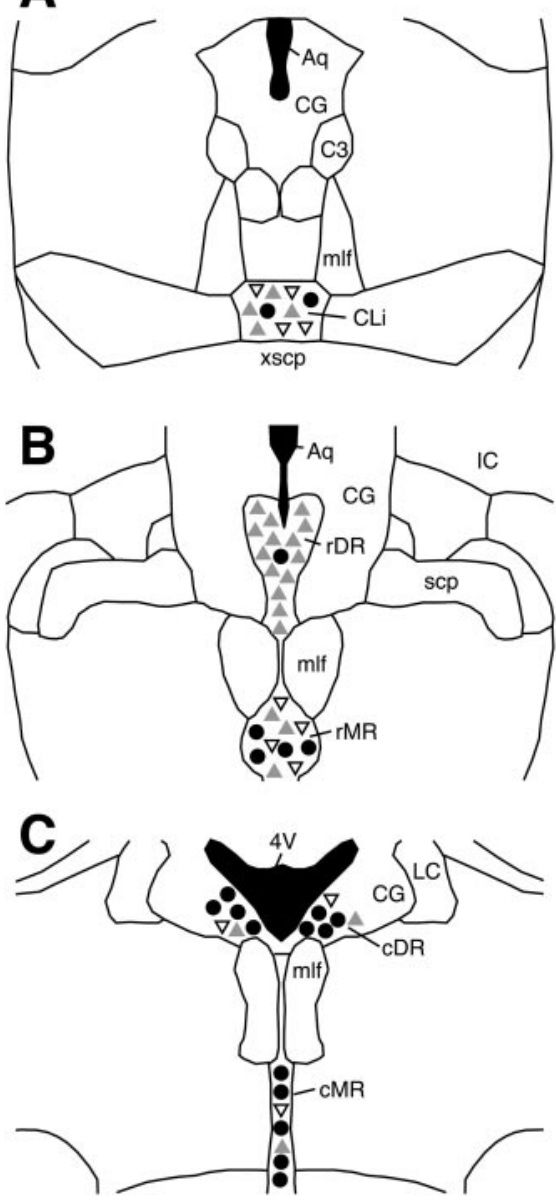

$\triangle \mathrm{SERT}$ mRNA $\nabla$ Ob-R mRNA • SERT/Ob-R mRNA

FIG. 1. Anatomical localization of SERT and Ob-R mRNA expression in the rostral brainstem of the monkey. Plates represent sections containing five regions of Raphe nuclei included in the analysis: $\mathrm{CLi}$ (A), rostral DR (rDR; B), rostral MR (rMR; B), caudal DR (cDR; C), and caudal MR (cMR; C). Symbols represent the locations of cells containing SERT mRNA (gray triangles), Ob-R mRNA (empty inverted triangles), or both SERT/Ob-R mRNAs (black circles). Aq, Cerebral aqueduct; CG, central gray; C3, oculomotor nucleus; mlf, medial longitudinal fasciculus; xscp, decussation of superior cerebellar peduncle; IC, inferior colliculus; scp, superior cerebellar peduncle; $4 \mathrm{~V}$, fourth ventricle; LC, locus coeruleus.

displayed as a cumulative density function in Fig. 3A. The ordinate value of each point represents the percentage of neurons with a SBR greater than a particular value (abscissa). This graph depicts the percentage of SERT mRNA-containing neurons considered to be double labeled for Ob-R mRNA at any threshold (SBR) level. Figure 3B presents the percentage of SERT mRNA-containing cells that also express Ob-R mRNA with a SBR greater than 5 for each anatomical region. Using a SBR of 5 as an arbitrary threshold, the percentage of double labeled cells varied considerably by anatomical region $(P<0.005$, by ANOVA). In the rostral DR, few SERT mRNA-positive cells had overlying clusters of silver grains, as reflected by the rapid decline in the cumulative density curve for this area (Fig. 3B). In contrast, a high percentage of cells in both the caudal DR and caudal MR expressed the mRNAs for both SERT and Ob-R (Fig. 3, A and B). An

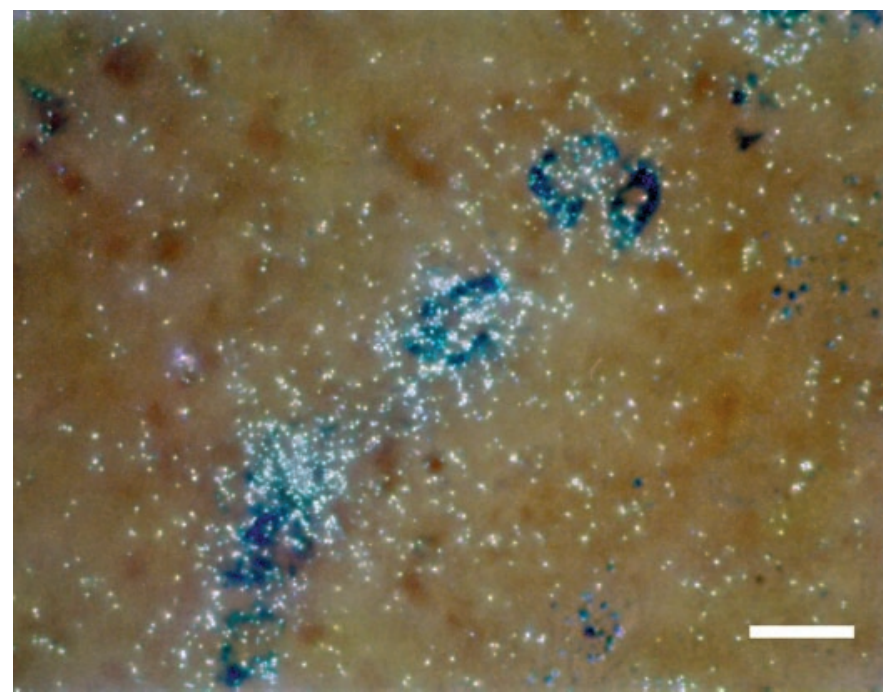

FIG. 2. Ob-R mRNA expression within SERT mRNA-expressing neurons in the DR. Representative neurons from the caudal DR that express mRNA for SERT (blue/purple precipitate) have overlying clusters of silver grains (white dots), indicating the presence of Ob-R mRNA. It should be noted that not all SERT mRNA-positive neurons in the caudal DR coexpress Ob-R mRNA. Scale bar, $30 \mu \mathrm{m}$.

intermediate level of double labeling was found in the CLi and rostral MR (Fig. 3B).

\section{Discussion}

Since the discovery that leptin acts as a signal to the central nervous system, regulating feeding, metabolism, and reproduction, considerable effort has been focused on elucidating the neuronal pathways by which leptin mediates these processes. Both neuropeptide $\mathrm{Y}$ and POMC are genes that are expressed in hypothalamic neurons that express $\mathrm{Ob}-\mathrm{R}$ mRNA, and these genes are regulated by leptin (23). Here we provide evidence that in the monkey, 5-HT neurons are included among the various phenotypes of neurons that are targets of leptin. We report that Ob-R mRNA is expressed in cells in the brainstem that also express the mRNA for SERT, a specific marker for 5-HT neurons. Using a conservative SBR of 5 , we estimate that approximately $40 \%$ of the 5 -HT neurons in the caudal portions of the DR and MR also express Ob-R mRNA.

The serotonin transporter is used by serotonergic neurons to clear 5-HT from the synaptic junction. In the rat, SERT mRNA expression in the Raphe nuclei is found exclusively in neurons that are immunoreactive for either tryptophan hydroxylase (the rate-limiting enzyme in 5-HT synthesis) or 5 -HT itself $(18,24)$. We cannot dismiss the possibility that some of the SERT mRNA-expressing cells may be glia, but the literature suggests that this is unlikely (25). The probe we used to detect Ob-R mRNA was targeted to a portion of the gene encoding the extracellular domain of the receptor; thus, in our double labeling experiment, we could not distinguish between the long form (signaling) and the short form (nonsignaling) of the receptor. However, subsequent experiments using a riboprobe specific to $\mathrm{Ob}-\mathrm{Rb}$ revealed that this isoform is present in the Raphe (our unpublished observation), making it likely that $5-\mathrm{HT}$ neurons actually express $\mathrm{Ob}-\mathrm{Rb}$. We 


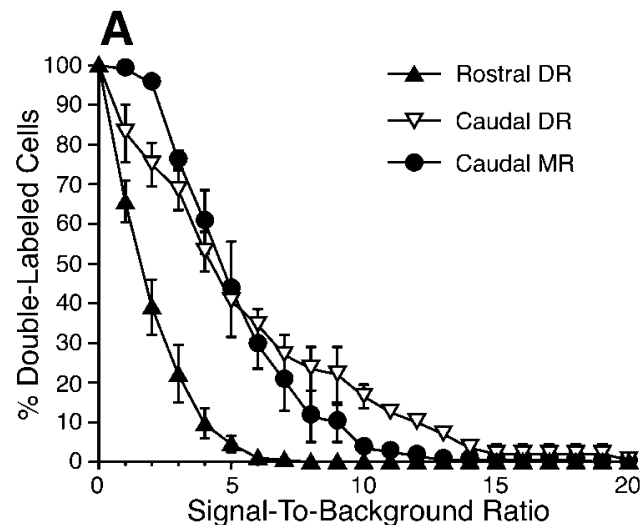

B

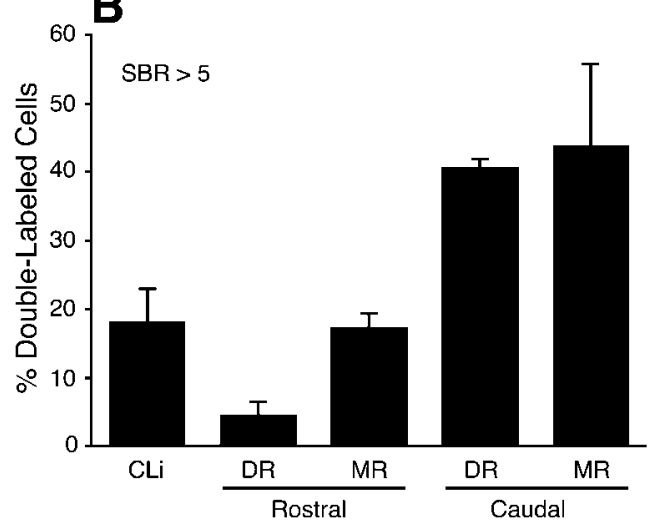

FIG. 3. Semiquantitative analysis of SERT/Ob-R mRNA coexpression. A, Percentage of 5-HT neurons considered to be double labeled as a function of varying SBR for rostral DR, caudal DR, and caudal MR. B, Bar graph indicating the percentage of cells considered double labeled for SERT/Ob-R mRNA using a criteria of SBR greater than 5 for all areas analyzed.

have provided an estimate of the percentage of SERT/Ob-R mRNA-expressing neurons as a function of SBR, allowing one to gauge the amount of coexpression based on different criteria.

The projections of 5-HT neurons have been studied in a variety of mammalian species, including nonhuman primates. Based on the patterns of development and connections in the adult monkey brain, the 5-HT system can be divided into two subsystems (26). The rostral subsystem (CLi, DR, and MR) projects expansively to the forebrain, whereas the caudal subsystem (magnus, obscurus, and pallidus Raphe nuclei) projects to the brainstem and spinal cord. Among the nuclei of the rostral subsystem, we observed a pronounced difference in the amount of Ob-R/SERT mRNA double labeling between the rostral and caudal Raphe nuclei. This distinction may have functional implications for leptin's actions on 5-HT neurons. Tract-tracing studies (using both antero- and retrograde tracing) involving the Raphe in rats indicate that there are differential projections to the forebrain from rostral and caudal portions of the DR $(27,28)$. A study of the projections of rostral vs. caudal MR found that although the MR projects to regions of the forebrain distinct from those innervated by the DR, there appear to be no major rostrocaudal differences in MR projections (29). The implications of the differential expression of Ob-R mRNA in the primate Raphe nuclei remain unknown, but may reflect leptin's targeting of specific afferents to the forebrain.

The present work offers evidence for colocalization of SERT and Ob-R mRNAs, suggesting that some of leptin's effects to suppress feeding may be mediated through alteration of serotonergic activity. It is well established that the 5-HT system influences feeding, as evidenced in part by the ability of 5-HT reuptake inhibitors such as fenfluramine and dexfenfluramine to inhibit food intake in primates $(30,31)$. Mice that are null mutants for the $5-\mathrm{HT}_{1 \mathrm{~B}}$ or $5-\mathrm{HT}_{2 \mathrm{C}}$ receptor subtype are less sensitive to the anorectic/satiating effects of fenfluramine/dexfenfluramine, implicating these receptor subtypes in mediating the effects of these drugs on feeding $(32,33)$, although only the $5-\mathrm{HT}_{2 \mathrm{C}}$ knockout mouse displays an obesity phenotype (34). Hypothalamic areas in which direct microinjection of serotonergic agents affect food intake in rats include the paraventricular (PVN) and ventromedial (VMN) nuclei (35). These two nuclei also show increased expression of the immediate-early gene product c-Fos after injection of the 5-HT reuptake inhibitor fluoxetine (36). The PVN and VMN are also implicated in leptin's action on feeding. The protein or mRNA for Ob-R is known to be expressed in these nuclei in rats $(15,37)$, and leptin injection induces expression of c-Fos in the VMN and PVN of fasted rats (38). Whether leptin activates the VMN/PVN indirectly (through 5-HT release) as well as directly (through Ob-R in the hypothalamus) remains to be elucidated.

5-HT may also play a role in mediating leptin's stimulatory effects on the reproductive axis. Most experiments investigating the effects of 5-HT on reproductive function have been performed in rats, where it seems that 5-HT can be either stimulatory or inhibitory to LH release depending on the circulating steroid milieu (17). There is also evidence implicating 5-HT in the regulation of sexual behavior as well as gonadotropin secretion in humans $(39,40)$. A direct effect of 5-HT on GnRH secretion is suggested by the observations that serotonergic fibers terminate in the proximity of $\mathrm{GnRH}$ perikarya/fibers (41). To date, little is known about the neural circuitry mediating leptin's effects on the reproductive system. The question of whether 5-HT plays a role in mediating leptin's effects on reproduction can only be answered after further experimentation.

In summary, the present results demonstrate coexpression of Ob-R and SERT mRNAs in neurons in the brainstem of the macaque. Although it has been established that leptin acts on the brain to influence feeding and reproduction, the detailed neural circuitry mediating these effects has been only partially elucidated, and the present work now extends the list of known targets for leptin's action to include 5-HT neurons in the brainstem of the monkey.

\section{Acknowledgments}

We thank Thomas Teal, Kevin Gobeske, and Jarrad Scarlett for their excellent technical assistance, and Dr. Clement Cheung, John Hohmann, and Stephanie Krasnow for their critical reading of the manuscript.

\section{References}

1. Cunningham MJ, Clifton DK, Steiner RA. 1999 Leptin's actions on the reproductive axis: perspectives and mechanisms. Biol Reprod. 60:216-222. 
2. Friedman JM, Halaas JL. 1998 Leptin and the regulation of body weight in mammals. Nature. 395:763-770.

3. Leibel RL, Chung WK, Chua Jr SC. 1997 The molecular genetics of rodent single gene obesities. J Biol Chem. 272:31937-31940.

4. Cheung CC, Clifton DK, Steiner RA. 1998 Leptin and its actions on reproduction. In: Hansel W, Bray GA, Ryan DH, eds. Nutrition and reproduction. Baton Rouge: Louisiana State University Press; vol 8:196-211.

5. Chehab FF, Lim ME, Lu R. 1996 Correction of the sterility defect in homozygous obese female mice by treatment with the human recombinant leptin. Nat Genet. 12:318-320.

6. Campfield LA, Smith FJ, Guisez Y, Devos R, Burn P. 1995 Recombinant mouse $\mathrm{OB}$ protein: evidence for a peripheral signal linking adiposity and central neural networks. Science. 269:546-549.

7. Tang-Christensen M, Havel PJ, Jacobs RR, Larsen PJ, Cameron JL. 1999 Central administration of leptin inhibits food intake and activates the sympathetic nervous system in rhesus macaques. J Clin Endocrinol Metab. 84:711-717.

8. Maffei M, Halaas J, Ravussin E, et al. 1995 Leptin levels in human and rodent: measurement of plasma leptin and $o b$ RNA in obese and weight-reduced subjects. Nat Med. 1:1155-1161.

9. Cameron JL, Nosbisch C. 1991 Suppression of pulsatile luteinizing hormone and testosterone secretion during short term food restriction in the adult male rhesus monkey (Macaca mulatta). Endocrinology. 128:1532-1540.

10. Ahima RS, Prabakaran D, Mantzoros C, Qu D, Lowell B, Maratos-Flier E, Flier JS. 1996 Role of leptin in the neuroendocrine response to fasting. Nature. 382:250-252.

11. Nagatani S, Guthikonda P, Thompson RC, Tsukamura H, Maeda K-I, Foster DL. 1998 Evidence for GnRH regulation by leptin: leptin administration prevents reduced pulsatile LH secretion during fasting. Neuroendocrinology. 67:370-376.

12. Finn PD, Cunningham MJ, Pau K-YF, Spies HG, Clifton DK, Steiner RA 1998 The stimulatory effect of leptin on the neuroendocrine reproductive axis of the monkey. Endocrinology. 139:4652-4662.

13. Kohsaka A, Watanobe H, Kakizaki Y, Habu S, Suda T. 1999 A significant role of leptin in the generation of steroid-induced luteinizing hormone and prolactin surges in female rats. Biochem Biophys Res Commun. 254:578-581.

14. Kalra SP, Kalra PS. 1996 Nutritional infertility: the role of the interconnected hypothalamic neuropeptide Y-galanin-opioid network. Front Neuroendocrinol. 17:371-401.

15. Elmquist JK, Bjørbæk C, Ahima RS, Flier JS, Saper CB. 1998 Distributions of leptin receptor mRNA isoforms in the rat brain. J Comp Neurol. 395:535-547.

16. Leibowitz SF, Alexander JT. 1998 Hypothalamic serotonin in control of eating behavior, meal size, and body weight. Biol Psychiatry. 44:851-864.

17. Vitale ML, Chiocchio SR. 1993 Serotonin, a neurotransmitter involved in the regulation of luteinizing hormone release. Endocr Rev. 14:480-493.

18. Rattray M, Michael GJ, Lee J, Wotherspoon G, Bendotti C, Priestley JV. 1999 Intraregional variation in expression of serotonin transporter messenger RNA by 5-hydroxytryptamine neurons. Neuroscience. 88:169-183.

19. Pecins-Thompson M, Brown NA, Bethea CL. 1998 Regulation of serotonin re-uptake transporter mRNA expression by ovarian steroids in rhesus macaques. Brain Res Mol Brain Res. 53:120-129.

20. Ramamoorthy S, Bauman AL, Moore KR, et al. 1993 Antidepressant- and cocaine-sensitive human serotonin transporter: molecular cloning, expression, and chromosomal localization. Proc Natl Acad Sci USA. 90:2542-2546.

21. Marks DL, Wiemann JN, Burton KA, Lent KL, Clifton DK, Steiner RA. 1992 Simultaneous visualization of two cellular mRNA species in individual neu- rons by use of a new double in situ hybridization method. Mol Cell Neurosci. 3:395-405.

22. Chan YY, Steiner RA, Clifton DK. 1996 Regulation of hypothalamic neuropeptide- $Y$ neurons by growth hormone in the rat. Endocrinology. 137:1319-1325.

23. Baskin DG, Hahn TM, Schwartz MW. 1999 Leptin sensitive neurons in the hypothalamus. Horm Metab Res. 31:345-350.

24. Hansson SR, Mezey E, Hoffman BJ. 1998 Serotonin transporter messenger RNA in the developing rat brain: early expression in serotonergic neurons and transient expression in non-serotonergic neurons. Neuroscience. 83:1185-1201.

25. Hoffman BJ, Hansson SR, Mezey E, Palkovits M. 1998 Localization and dynamic regulation of biogenic amine transporters in the mammalian central nervous system. Front Neuroendocrinol. 19:187-231.

26. Azmitia EC, Gannon PJ. 1986 The primate serotonergic system: a review of human and animal studies and a report on Macaca fascicularis. Adv Neurol. 43:407-468.

27. Imai H, Steindler DA, Kitai ST. 1986 The organization of divergent axonal projections from the midbrain raphe nuclei in the rat. J Comp Neurol. 243:363-380.

28. Vertes RP. 1991 A PHA-L analysis of ascending projections of the dorsal raphe nucleus in the rat. J Comp Neurol. 313:643-668.

29. Vertes RP, Fortin WJ, Crane AM. 1999 Projections of the median raphe nucleus in the rat. J Comp Neurol. 407:555-582.

30. Carek PJ, Dickerson LM. 1999 Current concepts in the pharmacological management of obesity. Drugs. 57:883-904.

31. Foltin RW, Fischman MW. 1988 Food intake in baboons: effects of d-amphetamine and fenfluramine. Pharmacol Biochem Behav. 31:585-592.

32. Lucas JJ, Yamamoto A, Scearce-Levie K, Saudou F, Hen R. 1998 Absence of fenfluramine-induced anorexia and reduced c-Fos induction in the hypothalamus and central amygdaloid complex of serotonin 1B receptor knock-out mice. J Neurosci. 18:5537-5544.

33. Vickers SP, Clifton PG, Dourish CT, Tecott LH. 1999 Reduced satiating effect of $d$-fenfluramine in serotonin 5- $\mathrm{HT}_{2 \mathrm{C}}$ receptor mutant mice. Psychopharmacology. 143:309-314.

34. Tecott LH, Sun LM, Akana SF, Strack AM, Lowenstein DH, Dallman MF Julius D. 1995 Eating disorder and epilepsy in mice lacking 5- $\mathrm{HT}_{2 \mathrm{C}}$ serotonin receptors. Nature. 374:542-546.

35. Leibowitz SF, Weiss GF, Suh JS. 1990 Medial hypothalamic nuclei mediate serotonin's inhibitory effect on feeding behavior. Pharmacol Biochem Behav. 37:735-742

36. Torres G, Horowitz JM, Laflamme N, Rivest S. 1998 Fluoxetine induces the transcription of genes encoding c-fos, corticotropin-releasing factor and its type 1 receptor in rat brain. Neuroscience. 87:463-477.

37. Håkansson M-L, Brown H, Ghilardi N, Skoda RC, Meister B. 1998 Leptin receptor immunoreactivity in chemically defined target neurons of the hypothalamus. J Neurosci. 18:559-572.

38. Elmquist JK, Ahima RS, Maratos-Flier E, Flier JS, Saper CB. 1997 Leptin activates neurons in ventrobasal hypothalamus and brainstem. Endocrinology. 138:839-842.

39. Lado-Abeal J, Rey C, Cabezas-Agricola JM, Rodriguez A, Camarero E, Cabezas-Cerrato J. 1997 L-Hydroxytryptophan amplifies pulsatile secretion of LH in the follicular phase of normal women. Clin Endocrinol (Oxf). 47:555-563.

40. Rosen RC, Lane RM, Menza M. 1999 Effects of SSRIs on sexual function: critical review. J Clin Psychopharmacol. 19:67-85.

41. Jennes L, Beckman WC, Stumpf WE, Grzanna R. 1982 Anatomical relationships of serotoninergic and noradrenalinergic projections with the $\mathrm{GnRH}$ system in septum and hypothalamus. Exp Brain Res. 46:331-338. 